\title{
Detection and cloning of LINE-1 elements in CHO cells
}

\author{
Olga Piskareva $\cdot$ Martin Clynes $\cdot$ Niall Barron
}

Published online: 6 April 2007

(C) Springer Science+Business Media B.V. 2007

\section{Erratum to: Cytotechnology DOI: 10.1007/s10616-007-9051-x}

This erratum is initiated in order to correct figure caption which appeared in article 10.1007/s10616007-9051-x.

Fig. 1 The caption for Fig. 1 should now be read as: Strategy for PCR amplification of L1 sequences from genomic DNA. (A) Structure of mammalian L1 element from $5^{\prime}$ to $3^{\prime}$ (scale is $\mathrm{kb}$ ). Open reading frames (ORFs) and untranslated regions (UTRs) are indicated by grey and black rectangles, respectively. (B) Schematic amino acid sequence alignment of rat and mouse L1 ORF2 sequences. Sources of elements and database accession numbers: L1Rn, rat (U83119); L1Md, mouse (AF081114). Seven peptide regions (Xiong and Eickbush 1990) which are common for retroelements are highlighted by empty rectangles. (C) Primer design for cloning L1 sequence from hamster genomic DNA. DNA alignment of rodent L1 ORF2 sequences. Conserved regions are indicated by stripped bars. Location of oligonucleotides producing DNA fragment in PCR and listed in Table 1 are shown by arrows

The online version of the original article can be found at http://dx.doi.org/10.1007/s10616-007-9051-x

O. Piskareva $(\varangle) \cdot$ M. Clynes · N. Barron National Institute for Cellular Biotechnology, DCU, Glasnevin, Dublin 9, Ireland e-mail: Olga.Piskareva@dcu.ie 